\title{
PENERAPAN MODEL DISCOVERY LEARNING UNTUK MENINGKATKAN AKTIVITAS BELAJAR DAN HASIL BELAJAR PESERTA DIDIK PADA MATERI LISTRIK STATIS KELAS IX SMP NEGERI 8 MAKASSAR
}

\author{
Andi Saddia \\ Universitas Sulawesi Barat \\ e-mail: andi_saddia@unsulbar.ac.id
}

\begin{abstract}
Abstrak
Penelitian ini bertujuan untuk meningkatkan aktivitas dan hasil belajar peserta didik pada materi listrik statis kelas IX SMP Negeri 8 Makassar melalui penerapan model Discovery Learning. Penelitian ini merupakan Penelitian Tindakan Kelas (PTK) yang dilaksanakan dalam dua siklus, dengan tiap siklus terdiri dari perencanaan, pelaksanaan tindakan, observasi, dan refleksi. Subjek penelitian adalah siswa kelas IX SMP Negeri 8 Makassar. Sumber data adalah guru dan siswa. Teknik pengumpulan data melalui observasi dan tes tertulis, selanjutnya dianalisis menggunakan deskriptif kualitatif. Berdasarkan hasil penelitian dapat disimpulkan bahwa penerapan model Discovery Learning dapat meningkatkan aktivitas dan hasil belajar siswa. Pada siklus I, persentase ketercapaian aktivitas belajar siswa sebesar $70 \%$ yang kemudian meningkat pada siklus II menjadi 81\%. Peningkatan hasil belajar siklus I mencapai 55,55\% dan meningkat pada siklus II menjadi $100 \%$.
\end{abstract}

Kata Kunci: Penelitian Tindakan Kelas, Discovery Learning, Aktivitas Belajar, Hasil Belajar, Listrik Statis

\section{APPLICATION OF DISCOVERY LEARNING MODEL TO IMPROVE STUDENT ACTIVITIES AND LEARNING OUTCOMES IN STATIC ELECTRICITY MATERIALS CLASS IX SMP NEGERI 8 MAKASSAR}

\begin{abstract}
This research to increase the activity and learning outcomes of students on static electricity for class IX SMP Negeri 8 Makassar through the application of the Discovery Learning model. This research is a Classroom Action Research (PTK) which is carried out in two cycles, with each cycle consisting of planning, implementing the action, observing, and reflecting. The research subjects were students of class IX SMP Negeri 8 Makassar. The data sources are teachers and students. Data collection techniques through observation and written tests, then analyzed using descriptive qualitative. Based on the research results, it can be concluded that the application of the Discovery Learning model can increase student activity and learning outcomes. In the first cycle, the percentage of student learning activity achievement was $70 \%$ which then increased in the second cycle to $81 \%$. The increase in learning outcomes in cycle I reached $55,55 \%$ and increased in cycle II to $100 \%$.
\end{abstract}

Keywords: Classroom Action Research, Discovery Learning, Learning Activities, Learning Outcomes, Static Electricity

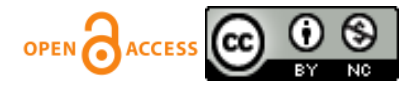




\section{PENDAHULUAN}

Proses pendidikan pada dasarnya bertujuan untuk menyiapkan peserta didik agar memiliki kompetensi sebagai bekal untuk dapat berperan dalam kehidupan di masa depan. Selain itu, pendidikan diharapkan agar dapat mengembangkan segala potensi yang dimiliki oleh peserta didik untuk menyiapkan sumber daya manusia yang berkualitas. Hal ini dapat diwujudkan melalui interaksi selama proses pembelajaran, baik melalui interaksi pendidik dengan peserta didik maupun interaksi antara peserta didik. Salah satu upaya yang dilakukan dalam rangka mengoptimalkan proses pendidikan adalah diberlakukan kurikulum 2013 yang disesuaikan dengan kebutuhan proses pembelajaran. Kurikulum 2013 bertujuan untuk mempersiapkan manusia Indonesia agar memiliki kemampuan hidup sebagai pribadi kreatif, inovatif, dan aktif melalui pembelajaran yang menekankan pada pendekatan saintifik (scientific approach).

Penelitian Tindakan Kelas adalah penelitian tindakan yang dilakukan oleh guru di dalam kelas [1]. Penelitian ini dilakukan ketika sekelompok orang (siswa) diidentifikasi permasalahannya, kemudian peneliti (guru) menetapkan suatu tindakan untuk mengatasinya [2]. Penelitian ini memberikan intervensi kecil terhadap tindakan di dunia nyata dan pemeriksaan cermat terhadap pengaruh intervensi tersebut [3]. Pandangan ini menunjukkan bahwa penelitian tindakan dapat dilakukan secara kolaboratif dengan pakar. Pakar memberikan alternatif pemecahan dan alternatif tersebut perlu diuji sejauh mana efektivitasnya.

Kemmis dan Taggart memandang, bahwa penelitian ini dilakukan secara kolektif untuk memperbaiki praktek yang mereka lakukan dan perbaikan dilakukan berdasar refleksi diri. Dalam bukunya Becoming Critical: Education, Knowledge, an Action Research 1986. Kemmis dan Carr lebih jelas menyatakan penelitian tindakan adalah bentuk penelitian refleksi diri yang dilakukan oleh partisipan (guru, siswa, atau kepala sekolah, misalnya) dalam situasi-situasi sosial (termasuk pendidikan) untuk memperbaiki rasionalitas dan kebenaran (a) praktek-praktek sosial atau pendidikan yang dilakukan sendiri, (b) pengertian mengenai praktek-praktek ini, dan (c) situasi-situasi (dan lembaga-lembaga) praktek-praktek tersebut dilaksanakan.

Penerapan model pembelajaran discovery learning untuk meningkatkan aktivitas dan prestasi belajar, diperoleh hasil bahwa pada setiap siklusnya mengalami peningkatan dari segi afektif dan kognitif peserta didik [4]. Penelitian tentang penerapan model pembelajaran discovery learning untuk meningkatkan hasil belajar siswa, pelaksanaan model discovery learning berbantuan alat peraga sederhana dilakukan melalui enam tahap yaitu stimulasi, identifikasi masalah, pengumpulan data dengan menggunakan alat peraga sederhana, pemrosesan data, verifikasi dan kesimpulan [5]. Penerapan model pembelajaran discovery learning untuk meningkatkan hasil belajar siswa, hasil temuan dan pembahasan, dapat direkomendasikan bahwa dengan menerapkan model discovery learning merupakan suatu alternatif untuk meningkatan hasil belajar siswa [6][7].

Pembelajaran IPA dengan menggunakan model Discovery Learning mampu mendorong peserta didik untuk aktif dalam membuat hipotesis, melakukan percobaan, menganalisis data dan membuat kesimpulan sehingga antusiasme peserta didik dalam proses belajar menjadi lebih meningkat dan dapat meningkatkan hasil belajar kognitif [8]. Keberhasilan suatu proses pembelajaran sangat dipengaruhi oleh faktor peserta didik itu sendiri karena merupakan komponen penting dalam sistem pembelajaran di sekolah sehingga dapat dikatakan bahwa peserta didik merupakan subjek dari proses dan aktivitas pembelajaran. Pembelajaran harus menjadi sebuah aktivitas yang berfokus pada peserta didik (learner centered), oleh karena itu sistem pembelajaran yang efektif dan 
efisien mempertimbangkan komponen karakteristik peserta didik [9]. Hasil penelitian yang lain menyatakan bahwa Discovery Learning adalah salah satu cara yang memberikan kesempatan kepada peserta didik untuk menemukan informasi dan terbukti meningkatkan kualitas pembelajaran dibandingkan dengan metode konvensional karena peserta didik dapat meningkatkan pengetahuan mereka selama proses pembelajaran. [10].

Seperti halnya di SMP Negeri 8 Makassar, mata pelajaran IPA menempati urutan kedua rendah hasil belajarnya setelah matematika, hal ini dibuktikan dengan nilai ujian akhir sekolah tiap tahunnya mengalami penurunan. Pada tahun 2016/2017 rata-rata skor hasil belajar siswa adalah 65,00. Lalu tahun 2017/2018 rata-rata skor hasil belajar siswa adalah yaitu 6,45, dengan nilai $\mathrm{kkm}$ yang ditetapkan yaitu 71,00.

Dari pemaparan diatas, terlihat bahwa terjadi penurunan. Oleh karena itu, perlu adanya upaya yang harus dilakukan oleh guru mata pelajaran IPA dalam mengatasi masalah ini termasuk memperbaiki model pembelajaran. Salah satu cara yang dapat dilakukan yaitu menerapkan model pembelajaran yang sesuai dengan karakteristik materi pelajaran agar peserta didik lebih aktif dalam proses pembelajaran, dalam hal ini model Discovery Learning diharapkan dapat membuat perubahan dalam proses pembelajaran.

\section{METODE}

Penelitian ini dilaksanakan di SMP Negeri 8 Makassar. Pelaku tindakan adalah peneliti berkolaborasi dengan guru IPA yang lain. Subjek penelitian adalah peserta didik kelas IX Tahun Ajaran 2017/2018 sebanyak 9 orang. Waktu pelaksanaan Penelitian tindakan kelas ini disesuaikan dengan jadwal mata pelajaran IPA di SMP Negeri 8 Makassar.

Penelitian ini merupakan penelitian tindakan kelas, dan proses pelaksanaan tindakan dilakukan secara bertahap yang terdiri atas dua siklus. Siklus I, II, dilakukan selama masing-masing 2 kali pertemuan (5 jam pelajaran) dan setiap siklus dilaksanakan evaluasi. Penelitian ini dilaksanakan dalam 2 siklus (siklus I, siklus II ), ntara pelaksanaan tindakan siklus I,siklus II merupakan rangkaian yang saling berkaitan dalam artian bahwa, pelaksanaan tindakan siklus II merupakan kelanjutan dan perbaikan dari pelaksanaan tindakan pada siklus I.

Proses tindakan yang dilakukan mengikuti model Kemmis dan Mc. Taggart yang terdiri dari 5 komponen yaitu permasalahan, perencanaan tindakan, pelaksanaan tindakan, observasi dan refleksi [11]. Instrumen yang digunakan pada penelitian ini adalah lembar observasi keaktifan peserta didik, dan tes hasil belajar. Instrumen yang digunakan pada penelitian ini adalah lembar observasi keaktifan peserta didik, dan tes hasil belajar.

Sumber data berasal dari hasil tes dan non tes sementara jenis data terdiri dari data kualitatif yang merupakan deskripsi dari hasil penelitian observasi dan kondisi pembelajaran, catatan aktivitas guru dan peserta didik, serta absensi dan data kuantitatif yang berupa hasil belajar peserta didik yang diambil dari nilai hasil ulangan di setiap siklus. Instrumen penelitian terdiri dari lembar angket peserta didik, lembar pengamatan proses pembelajaran, lembar tugas peserta didik, dan lembar ulangan tiap siklus.

Teknik observasi dilakukan secara langsung terhadap peserta didik, sehingga akan diperoleh gambaran yang jelas dan akan membantu mempermudah penelitian yang akan dilakukan. Tes tertulis dilakukan juga untuk memperoleh data tentang kemampuan untuk memahami konsep yang diajarkan baik sebelum maupun sesudah pembelajaran dengan model Discovery Learning. Analisis kualitatif menggunakan teknik kategorisasi standar dalam penentuan nilai rapor dan kenaikan kelas yang ditetapkan oleh Departemen Pendidikan dan Kebudayaan [12]. 


\section{HASIL DAN PEMBAHASAN}

\section{Hasil}

Tabel 1. Ketuntasan Hasil Belajar Peserta didik pada Siklus I

\begin{tabular}{ccc}
\hline Nama & $\begin{array}{c}\text { Tes Akhir } \\
\text { siklus I }\end{array}$ & Keterangan \\
\hline SH & 50 & Tidak tuntas \\
AS & 80 & Tuntas \\
AG & 80 & Tuntas \\
NV & 80 & Tuntas \\
DA & 80 & Tuntas \\
HS & 70 & Tidak tuntas \\
EF & 80 & Tuntas \\
RZ & 60 & Tidak Tuntas \\
AK & 60 & Tidak Tuntas \\
\hline \multicolumn{3}{c}{$\mathbf{5}$} \\
\hline \multicolumn{3}{c}{$\mathbf{5 5 , 5 5 \%}$} \\
\hline
\end{tabular}

Tabel 2. Distribusi Skor Hasil Belajar Peserta didik pada Siklus I

\begin{tabular}{cccc}
\hline Interval & $\mathbf{F}$ & $\begin{array}{c}\text { Persentase } \\
(\boldsymbol{\%})\end{array}$ & Kategori \\
\hline $0-63$ & 0 & 0,00 & Sangat Rendah \\
$64-72$ & 2 & 22,22 & Rendah \\
$73-81$ & 4 & 44,44 & Sedang \\
$82-90$ & 3 & 33,33 & Tinggi \\
$90-100$ & 0 & 0,00 & Sangat Tinggi
\end{tabular}

Tabel 3. Persentase Ketuntasan belajar peserta didik pada Siklus I Interval $\mathbf{F}$ Persentase Kategori

\begin{tabular}{cccc}
\multicolumn{5}{c}{$(\boldsymbol{\%})$} \\
\hline $0-72$ & 6 & $66,66 \%$ & Tidak Tuntas \\
$73-100$ & 3 & $33,33 \%$ & Tuntas \\
\hline
\end{tabular}

\section{Hasil Belajar Siswa pada Siklus II}

Tabel 4. Ketuntasan Hasil Belajar peserta didik pada Siklus II

\begin{tabular}{ccc}
\hline Nama & $\begin{array}{c}\text { Tes Akhir } \\
\text { siklus II }\end{array}$ & Keterangan \\
\hline SH & 80 & Tuntas \\
AS & 90 & Tuntas \\
AG & 80 & Tuntas \\
NV & 80 & Tuntas \\
DA & 90 & Tuntas \\
HS & 80 & Tuntas \\
EF & 80 & Tuntas \\
RZ & 80 & Tuntas \\
AK & 80 & Tuntas \\
\hline \multicolumn{4}{c}{$\mathbf{9}$} \\
\hline \multicolumn{4}{c}{$\mathbf{1 0 0} \%$} \\
\hline
\end{tabular}


Tabel 5. Distribusi Skor Hasil Belajar peserta didik pada Siklus II

\begin{tabular}{cccc}
\hline Interval & $\mathbf{F}$ & $\begin{array}{c}\text { Persentase } \\
(\%)\end{array}$ & Kategori \\
\hline $0-63$ & 0 & 0,00 & Sangat Rendah \\
$64-72$ & 0 & 0,00 & Rendah \\
$73-81$ & 7 & 77,77 & Sedang \\
$82-90$ & 2 & 22,22 & Tinggi \\
$91-100$ & 0 & 0,00 & Sangat Tinggi \\
\hline
\end{tabular}

Tabel 6. Persentase Ketuntasan belajar peserta didik pada Siklus II

\begin{tabular}{cccc}
\hline Interval & $\mathbf{F}$ & $\begin{array}{c}\text { Persentase } \\
(\boldsymbol{\%})\end{array}$ & Kategori \\
\hline $0-72$ & 0 & $0,0 \%$ & Tidak Tuntas \\
$73-100$ & 9 & $100,00 \%$ & Tuntas \\
\hline
\end{tabular}

Tabel 7. Aktivitas Peserta Didik Siklus I

\begin{tabular}{|c|c|c|c|c|c|c|c|c|c|c|c|c|}
\hline \multirow[t]{2}{*}{ No. } & \multirow{2}{*}{$\begin{array}{c}\text { Nama } \\
\text { Peserta } \\
\text { Didik }\end{array}$} & \multicolumn{9}{|c|}{ Aktivitas Peserta Didik } & \multirow[t]{2}{*}{ Jumlah } & \multirow[t]{2}{*}{ Persentase } \\
\hline & & 1 & 2 & 3 & 4 & 5 & 6 & 7 & 8 & 9 & & \\
\hline 1 & SH & 3 & 3 & 2 & 2 & 2 & 3 & 2 & 3 & 4 & 24 & $67 \%$ \\
\hline 2 & AS & 4 & 4 & 4 & 3 & 3 & 3 & 3 & 3 & 4 & 31 & $86 \%$ \\
\hline 3 & AG & 4 & 4 & 3 & 2 & 3 & 2 & 3 & 3 & 4 & 28 & $78 \%$ \\
\hline 4 & NV & 3 & 3 & 3 & 3 & 2 & 2 & 3 & 3 & 4 & 26 & $72 \%$ \\
\hline 5 & DA & 2 & 3 & 2 & 2 & 2 & 2 & 2 & 3 & 4 & 22 & $61 \%$ \\
\hline 6 & HS & 2 & 3 & 2 & 2 & 2 & 2 & 2 & 3 & 4 & 22 & $61 \%$ \\
\hline 7 & $\mathrm{EF}$ & 4 & 3 & 3 & 3 & 3 & 4 & 3 & 3 & 4 & 30 & $83 \%$ \\
\hline 8 & $\mathrm{RZ}$ & 3 & 2 & 2 & 2 & 2 & 3 & 2 & 3 & 4 & 23 & $63 \%$ \\
\hline 9 & $\mathrm{AK}$ & 3 & 2 & 2 & 2 & 2 & 3 & 2 & 3 & 4 & 23 & $63 \%$ \\
\hline \multicolumn{2}{|c|}{ JUMLAH } & 28 & 27 & 23 & 21 & 21 & 24 & 22 & 27 & 36 & 229 & \\
\hline \multicolumn{2}{|c|}{$\begin{array}{c}\text { Persentase Per } \\
\text { item }(\%)\end{array}$} & 78 & 75 & 63 & 58 & 58 & 67 & 61 & 75 & 100 & $70 \%$ & \\
\hline
\end{tabular}


Tabel 8. Aktivitas Peserta Didik Siklus II

\begin{tabular}{|c|c|c|c|c|c|c|c|c|c|c|c|c|}
\hline \multirow[t]{2}{*}{ No } & \multirow{2}{*}{$\begin{array}{c}\text { Nama } \\
\text { Peserta } \\
\text { Didik }\end{array}$} & \multicolumn{9}{|c|}{ Aktivitas Peserta Didik } & \multirow[t]{2}{*}{ Jumlah } & \multirow[t]{2}{*}{ Persentase } \\
\hline & & 1 & 2 & 3 & 4 & 5 & 6 & 7 & 8 & 9 & & \\
\hline 1 & SH & 4 & 3 & 3 & 3 & 3 & 2 & 2 & 3 & 4 & 27 & $75 \%$ \\
\hline 2 & AS & 4 & 4 & 4 & 3 & 3 & 4 & 3 & 3 & 4 & 32 & $89 \%$ \\
\hline 3 & $A G$ & 4 & 4 & 3 & 3 & 3 & 3 & 3 & 3 & 4 & 30 & $83 \%$ \\
\hline 4 & NV & 4 & 3 & 3 & 3 & 3 & 3 & 3 & 3 & 4 & 29 & $81 \%$ \\
\hline 5 & DA & 4 & 3 & 3 & 3 & 3 & 3 & 3 & 3 & 4 & 29 & $81 \%$ \\
\hline 6 & HS & 4 & 3 & 2 & 3 & 2 & 3 & 2 & 3 & 4 & 26 & $72 \%$ \\
\hline 7 & $\mathrm{EF}$ & 4 & 4 & 4 & 3 & 3 & 4 & 3 & 3 & 4 & 32 & $89 \%$ \\
\hline 8 & $\mathrm{RZ}$ & 4 & 3 & 3 & 3 & 3 & 3 & 3 & 3 & 4 & 29 & $81 \%$ \\
\hline 9 & AK & 4 & 3 & 3 & 3 & 3 & 3 & 3 & 3 & 4 & 29 & $81 \%$ \\
\hline \multicolumn{2}{|c|}{ JUMLAH } & 36 & 30 & 28 & 27 & 26 & 28 & 25 & 27 & 36 & 263 & \\
\hline \multicolumn{2}{|c|}{$\begin{array}{l}\text { Persentase Per } \\
\text { item }(\%)\end{array}$} & 100 & 83 & 78 & 75 & 72 & 78 & 69 & 75 & 100 & $81 \%$ & \\
\hline
\end{tabular}

Banyak peserta didik : 1 bila $>40 \% ; 2$ bila $40 \%$ sampai $>60 \%$ skor 3 bila $60 \%$ sampai $80 \%$; skor 4 bila $80 \%$ sampai $100 \%$ aktif

Kualitas :

$\begin{array}{ll}\text { Sangat Baik } & \text { : skor } 4 \\ \text { Baik } & : \text { skor } 3 \\ \text { Cukup } & \text { : skor 2 } \\ \text { Kurang } & \text { : skor1 }\end{array}$

Rumus menghitung skor pemerolehan:

$\frac{\text { Jumlah Skor perolehhan }}{\text { skor Keseluruhan }} \times 100$

Dalam upaya meningkatkan hasil belajar IPA yang dihadapi peserta didik, terdapat beberapa faktor-faktor yang perlu diperhatikan, yaitu motivasi peserta didik, keaktifan peserta didik serta responsial terhadap proses pembelajaran. Perubahan tersebut merupakan data kualitatif yang diperoleh dari lembar observasi pada setiap pertemuan yang dicatat oleh observer pada setiap siklus. Perubahan tersebut mengalami peningkatan dari siklus I dan siklus II. pada siklus I keaktifan peserta didik mencapai $70 \%$, pada siklus II keaktifan peserta didik mencapai $81 \%$, itu berarti bahwa keaktifan peserta didik dari siklus I hingga siklus II mengalami peningkatan.

\section{Pembahasan}

Berdasarkan hasil analisis data yang dilakukan maka hasil penelitian ini mengungkapkan bahwa peserta didik yang semula memiliki skor hasil belajar IPA yang berada pada kategori 'sedang' dapat ditingkatkan melalui pembelajaran dengan model Discovery Learning. Peningkatan skor rata-rata yang diperoleh peserta didik terlihat dengan meningkatnya frekuensi dan persentase keaktifan peserta didik dalam mengikuti proses belajar mengajar.

Menurut kriteria ketuntasan minimal (KKM) berdasarkan kompetensi dasar SMP Negeri 8 Makassar yaitu 73, hasil tes pada siklus I menunjukkan bahwa skor hasil belajar IPA peserta didik berkisar 71,1, maka dikatakan bahwa keberhasilan 
peserta didik terhadap pembelajaran melalui model Discovery Learning pada siklus I belum tercapai.

Jumlah peserta didik yang mencapai KKM dibawah $85 \%$, hanya 5 peserta didik atau 55,55\% dari jumlah seluruh peserta didik, pada siklus II tes hasil belajar IPA melalui pembelajaran melalui model Discovery Learning mencapai persentase $100,0 \%$. Dengan persentase tersebut pada siklus II ketuntasan belajar IPA melalui pembelajaran dengan model Discovery Learning meningkat. Sehingga dapat disimpulkan bahwa dari siklus I ke siklus II terjadi peningkatan hasil belajar melalui Discovery Learning peserta didik yang ditandai oleh ketuntasan belajar meningkat dari 55,55 \% menjadi 100,0 \% sehingga peningkatan ketuntasan belajar dari siklus I ke siklus II mencapai peningkatan 44,45 \%.

Untuk aktivitas peserta didik berdasarkan data yang telah diperoleh, selama tiga siklus ini telah mengalami peningkatan dari setiap siklusnya. Rangkuman hasil observasi aktivitas peserta didik selama tiga siklus adalah sebagai berikut. Siklus I mencapai persentase yang cukup baik yakni $70 \%$. Pada siklus II mengalami peningkatan hingga mencapai persentase, yaitu $81 \%$. Aspek yang dijadikan penilaian pada observasi aktivitas peserta didik dalam pembelajaran Listrik Statis ini adalah terdiri dari masuk kelas tepat waktu, perhatian peserta didik terhadap guru saat menyampaikan materi, peserta didik aktif saat mengamati, keaktifan peserta didik dalam bertanya, keaktifan peserta didik dalam menjawab pertanyaan, interaksi peserta didik saat melakukan diskusi secara berkelompok, ketertiban saat mengikuti proses pembelajaran, penampilan hasil kerja peserta didik dalam kelompok (presentasi), dan pengerjaan evaluasi hasil pembelajaran.

Pada siklus I peserta didik masih sebagian yang ikut terlibat aktif pada setiap kegiatan. Begitu juga untuk aspek Interaksi peserta didik saat melakukan diskusi secara berkelompok masih ada peserta didik yang belum aktif melakukan diskusi kelompok. Selanjutnya berdasarkan temuan esensial pada siklus II, pelaksanaan pembelajaran dengan model discovery learning meningkat dan dapat dikatakan sangat memuaskan. Hal ini dapat dilihat dari aktivitas peserta didik dan penilaian hasil belajar.

Pada aktivitas peserta didik, seperti mengutarakan dan menyanggah pendapat sudah terjadi dengan sangat baik, peserta didik mau menerima pendapat orang lain, mau bekerja sama dalam kelompok, dominasi kelompok peserta didik tertentu tidak nampak lagi, serta berbagai kegiatan yang dilakukan oleh setiap peserta didik dilakukan dengan penuh tanggung jawab. Pada saat presentasi peserta didik sudah dapat melakukan dengan baik, mau mendengarkan, juga menerima pendapat temannya, serta mampu memberikan alasan terhadap hasil presentasinya. Selain itu keberhasilan pembelajaran pada siklus II ini dibuktikan dengan meningkatnya setiap aspek penilaian yang dilaksanakan baik aspek proses maupun hasil belajar.. Selain itu juga peserta didik lebih cepat dalam menyelesaikan tugas yang ada dalam LKPD.

Selain itu, jumlah peserta didik yang tuntas pada siklus I mengalami peningkatan pada siklus II yaitu dari 5 menjadi 9 peserta didik atau meningkat sebanyak 4 peserta didik atau 44,44 \%. Sedangkan jumlah peserta didik yang belum tuntas pada siklus I sebanyak 4 pada siklus II sebanyak 0 , pelaksanaan pembelajaran dengan model discovery learning dikatakan cukup memuaskan. Guru melakukan perbaikan pembelajaran berdasarkan hasil analisis dan refleksi pada siklus sebelumnya.

Guru dapat memotivasi peserta didik dengan memberikan penguatan, menjelaskan materi maupun pembentukan kelompok dilakukan dengan dipahami oleh peserta didik. Hal ini ditunjukkan saat peserta didik bekerja dalam kelompoknya, aktivitas peserta didik sudah meningkat dibandingkan pada pembelajaran sebelumnya. Dalam mengerjakan LKPD pun sebagian besar kelompok sudah dapat menyelesaikan permasalahan yang harus diselesaikan. Dengan demikian 
pembelajaran dengan menggunakan model discovery learning pada materi perubahan Listrik Statis pada siklus II ini sudah sesuai dengan harapan.

Berdasarkan data diatas, seluruh poin yang menjadi penilaian penelitian sudah mencapai target, bahkan melebih target yang telah ditentukan. aktivitas peserta didik dan hasil belajar mencapai target pada siklus II. Selama proses penelitian, peneliti menemukan beberapa temuan pada penelitian ini. Temuan-temuan yang diperoleh selama melakukan penelitian diantaranya bahwa dalam pembelajaran IPA, tidak semua materi dapat disampaikan dengan metode ceramah saja, tetapi ada beberapa materi yang memerlukan metode, strategi, pendekatan ataupun model pembelajaran yang bervariasi sehingga membuat peserta didik untuk lebih aktif dan termotivasi untuk belajar. Guru hendaknya banyak memberikan rangsangan kepada peserta didik agar mau berinteraksi dengan lingkungan secara aktif, mencari dan menemukan berbagai hal dari lingkungan. Dari temuan itulah peneliti memilih model discovery learning, karena melalui model tersebut peserta didik melakukan percobaan, bagi anak usia Sekolah Menengah Pertama pembelajaran akan lebih menarik dengan percobaan, karena dengan percobaan peserta didik melakukan penemuan sendiri, tidak hanya teori yang diterima peserta didik namun ada kesinambungan dan pembuktian antara teori dengan fakta.

Pemaparan diatas sesuai dengan kelebihan-kelebihan model discovery learning yang diungkapkan oleh (Ilahi, 2012) yaitu model ini kegiatan dan pengalaman dilakukan secara langsung sehingga lebih menarik perhatian peserta didik untuk belajar dan memungkinkan pembentukan konsep-konsep abstrak yang mempunyai makna, serta memberi banyak kesempatan bagi peserta didik untuk terlibat langsung dalam kegiatan belajar [13]. Penerapan model discovery learning disesuaikan dengan teori konstruktivisme Bruner yang mencakup gagasan belajar sebagai proses aktif, pembelajaran tersebut mampu membentuk ide-ide baru berdasarkan pada pengetahuan mereka saat ini serta pengetahuan masa lalu mereka.

Model ini pun dapat merubah apa yang awalnya peserta didik pahami secara abstrak menjadi konkrit. Pembelajaran dengan menerapkan model discovery learning pun secara tidak langsung sudah melaksanakan apa yang sebenarnya harus ada dalam pembelajaran IPA, yaitu memberikan pengalaman langsung, melakukan pengamatan, memahami hasil pengamatan, hingga menerapkan konsep. Dengan demikian alternatif pemecahan masalah yang diambil dengan menerapkan model discovery learning untuk mengatasi masalah yang ditemukan.

Peningkatan hasil belajar tersebut disebabkan oleh peningkatan keaktifan peserta didik dalam proses pembelajaran. Peserta didik berpartisipasi aktif dalam kegiatan pembelajaran, dalam proses pembelajaran peserta didik sudah memiliki kemampuan bekerjasama dan memiliki keberanian untuk mengemukakan pendapatnya. Melalui penelitian ini menunjukkan bahwa penerapan model Discovery Learning memiliki dampak positif dalam meningkatkan hasil belajar peserta didik. Hal ini dapat dilihat dari semakin meningkatnya hasil belajar peserta didik dan semakin mantapnya pemahaman materi pembelajaran peserta didik terhadap materi yang disampaikan guru dan ketuntasan belajar meningkat dari siklus I sampai siklus II.

\section{SIMPULAN DAN SARAN Simpulan}

Peningkatan aktivitas belajar dan Hasil belajar IPA peserta didik dengan menerapkan model Discovery Learning pada kelas IX SMP Negeri 8 Makassar ditunjukkan dengan rata-rata perolehan skor tes akhir berada pada kategori tinggi. Menurut kriteria ketuntasan minimal (KKM) berdasarkan kompetensi dasar SMP Negeri 8 Makassar yaitu 73, hasil tes pada siklus I menunjukkan bahwa 
persentase skor hasil belajar IPA peserta didik berkisar 55,55 \%, pada siklus II mencapai 100,0\%, maka dikatakan bahwa keberhasilan peserta didik terhadap pembelajaran melalui model Discovery Learning pada siklus I belum tercapai karena jumlah peserta didik yang mencapai KKM dibawah $73 \%$ dari jumlah seluruh peserta didik. $P$

Pada siklus II, tes hasil belajar IPA melalui pembelajaran dengan model Discovery Learning. mencapai persentase ketuntasan hingga $100 \%$. Dengan persentase tersebut pada siklus I dan siklus II ketuntasan belajar IPA melalui pembelajaran melalui model Discovery Learning meningkat. Sehingga dapat disimpulkan bahwa pada siklus I dan II terjadi peningkatan hasil belajar peserta didik yang ditandai oleh ketuntasan belajar meningkat dari 55,55\%, menjadi $100,0 \%$, sehingga meningkatkan ketuntasan belajar mencapai 44,45\%.l

Pembelajaran melalui model Discovery Learning dapat meningkatkan hasil belajar IPA peserta didik karena dalam pembelajaran ini peserta didik dihadapkan langsung dengan fenomena atau peristiwa yang berhubungan dengan materi yang akan dipelajari dalam hal ini adalah pelaksanaan demonstrasi, sehingga dengan melihat fenomena tersebut peserta didik dapat mengungkapkan pendapat atau gagasan-gagasan yang mereka miliki dan kemudian mereka menghubungkan dengan konsep-konsep yang ada dan juga mereka harus mengetahui pengaplikasian dari pada konsep tersebut, hal ini sangat membantu peserta didik untuk memahami materi yang sedang dipelajari dan dapat mengingatnya dalam waktu yang lama daripada mereka hanya mendengarkan dan menghayalkan materi yang dipelajari karena dalam pembelajaran ini peserta didik dituntut untuk lebih aktif, guru hanya berperan sebagai fasilitator.

\section{Saran}

Saran Bagi peserta didik, Hendaknya menghilangkan rasa kurang percaya diri.
Saran Bagi Guru, Pendekatan pribadi guru terhadap peserta didik perlu dilakukan agar peserta didik memperoleh kepercayaan diri dan merasa ada suasana baru dalam pembelajaran.

Saran Bagi Sekolah, Pengadaan media pembelajaran serta perangkat pendukung lainya hendaknya terus dilakukan agar pembelajaran dapat dilaksanakan secara optimal.

Saran Bagi Peneliti, Dapat menjadi bahan rujukan untuk melakukan kegiatan penelitian selanjutnya.

\section{DAFTAR PUSTAKA}

[1] Kusuma, Wijaya. Penelitian Tindakan Kelas. 2011. Jakarta: PT Indeks.

[2] Mulyatiningsih, Endang. Metode Penelitian Terapan Bidang Pendidikan. 2011. Bandung: Alfabeta.

[3] Padmono. Kekurangan dan kelebihan, Manfaat Penerapan PTK. 2010. Tersedia: http//edukasi.kompasiana.com/2010/ 10/19/kekurangan-kelebihanmanfaatdan penerapan-ptk.

[4] Istiana, dkk. Penerapan model pembelajaran discovery learning untuk meningkatkan aktivitas dan prestasi belajar pokok bahasan larutan penyangga pada siswa kelas xi ipa Semester II SMA Negeri 1 Ngemplak Tahun pelajaran 2013/2014. Jurnal Pendidikan Kimia (JPK), 2015. Vol. 4

http://jurnal.fkip.uns.ac.id/index.php/ kimia

[5] Suprayanti, dkk. Penerapan Model Discovery Learning Berbantuan Alat Peraga Sederhana untuk Meningkatkan Aktivitas dan Hasil Belajar Siswa Kelas VII SMPN 5 Jonggat Tahun Pelajaran 2015/2016. Jurnal Pendidikan Fisika dan Teknologi. 2016. Vol 2 (1).

[6] Rosarina, dkk. Penerapan model discovery learning untuk meningkatkan hasil belajar siswa 
pada materi perubahan wujud benda. Jurnal Pena Ilmiah. 2016. Vol. 1 (1).

[7] Wahyudi. Penerapan discovery learning dalam pembelajaran ipa sebagai upaya untuk meningkatkan hasil belajar siswa kelas IX-I di SMP Negeri 1 Kalianget. Jurnal Lentera Sains (Lensa). 2015. Vol 5(1).

[8] Yuliani et al, Pembelajaran Model Discovery Learning dan Strategi Bowling Kampus untuk Meningkatkan Hasil Belajar Kognitif dan Motivasi Belajar IPA. Bioedukasi. $2017 . \quad$ DOI: http://dx.doi.org/10.20961/bioedukas i-uns.v10i1.8780

[9] Nuraini. Intensitas Belajar Siswa. 2011.

http://suaraguru.wordpress.com/2011 /12/01/.

[10] In'am, A., Hajar, S. Learning Geometry through Discovery Learning Using a Scientific Approach. International Journal of Instruction. 2017. Vol.10(1): 55-70.

[11] Widayanti. Penelitian Tindakan Kelas. Jurnal Pendidikan Akuntansi Indonesia. Vol 6 (1). 2008.

[12] Humairah, NA. Upaya Meningkatkan Hasil Belajar Fisika melalui Penggunaan Peta Konsep Dalam Pembelajaran Fisika pada Siswa Kelas VII Smp Negeri 1 Campalagian Kabupaten Polewali Mandar. Jurnal saintifik. 2017. Vol 3 (1).

[13] Illahi, Mohammad Takdir. Pembelajaran Discovery Strategy dan Mental Vocational Skill. 2012. Jogjakarta: Diva Press. 